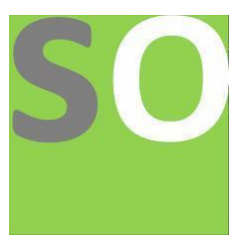

Article title: Failure in building and remedies

Authors: SAMUEL OKOLO KENECHI[1]

Affiliations: Opposite Amata community school Mgbowo,Awgu Enugu State[1]

Orcid ids: 0000-0002-8519-5390[1]

Contact e-mail: samuelokolo1@gmail.com

License information: This work has been published open access under Creative Commons Attribution License http://creativecommons.org/licenses/by/4.0/, which permits unrestricted use, distribution, and reproduction in any medium, provided the original work is properly cited. Conditions, terms of use and publishing policy can be found at https://www.scienceopen.com/.

Preprint statement: This article is a preprint and has not been peer-reviewed, under consideration and submitted to ScienceOpen Preprints for open peer review.

DOI: 10.14293/S2199-1006.1.SOR-.PPUBO0E.v1

Preprint first posted online: 03 November 2021 


\section{FAILURE IN BUILDING AND REMEDIES}

Bldr Keftin Namala and Okolo K. Samuel, Department of Building, Federal University of Technology Yola, Nigeria.

The research investigates the causes of failure in buildings (failure on floors, walls or block works and roofing) for the purpose of this research, the surveying of the various sites of the areas under study was undertaken from the sites surveying, it was found that the common factors that are causing these failures in the area under study are environmental factors, poor drainage system and poor execution method. Thus, the study recommends the possible solutions to the identified problems on the study area.

\section{INTRODUCTION}

KEYWORD: Failure, Building, Remedies.

Building failures, according to Eldrege (1976) are problems experienced anywhere in the world. The problems are either caused naturally or caused due to lack of knowledge or negligence from human beings. In industrialized countries, from their experience of building in wide range of techniques, have developed systems of control by regulations, codes of practice and standardization to help prevent building techniques, particularly due to unfamiliar use of some materials that are introduced from abroad, and also the geographical location could also affect the nature of buildings due to environmental agencies. Building regulations which provide the basis for the assessment of failure vary from one country to another as a result of technological, economic and socio-cultural differences. The environmental agencies such as radiation from the unsatisfactory design of execution, but still fault occur.

Building failure was expressed by Ikpo (1998) as the level of deviation from the as "asbuilt" state which describe the generally accepted standard within the neighbourhood, locality, state or country. In developing countries like Nigeria, the problems of avoiding defect are frequently greater due to lack of experience of some

sun, varying in amount, direction, intensity and spectral composition, rain varying in direction, quantity, intensity, direction and distribution and wind action also cause failure of building. Other factors which are as a result of human negligence include poor planning, designing, inadequate construction and supervision method as well as the use of inferior materials for the construction of buildings. 
Richardson (1991), stated that the main function of the building is to protect the occupants and contents from the weather, principally rain, wind and extremes of temperature. It is mot important to provide a simple intact envelop which will achieve all of these functions; features such as windows, flue, damp-proof courses and thermal insulation are only additional sophistications. Obviously a building must be structurally sound in order to survive.

According to Afolabi (2000), he stated that buildings are Civil Engineering Construction Projects that provide shelter for human beings, used for offices, schools, hospitals, mosques, churches, hotels, shopping malls and complexes, banks and so on. Richardson (1991) further stated that structural failures are the result of over-stressing, that is the imposition of loads in excess of the capacity of the structural components. Collapse is of course, the ultimate and most serious result, but over-stressing is also evident at earlier stages through development of distortion and fractures.

Oloyede, et al (2010) attributed causes of building collapse as due to man's negligence in some vital areas in construction such as soil investigation, incorporating design for extra

loads, stress from winds, earthquakes, uneven terrain, use of substandard building materials, poor monitoring and overall poor workmanship.

Madu, 2005, identified causes of building failure as due to natural occurrences such as earthquakes, tornadoes, flood, etc. Other causes according to him include factors such as omission, carelessness, leading to use of deficient structural drawings, absence of proper supervision of projects, alteration of approved drawings, use of substandard materials, corruption in the Nigerian system, building without approved drawings and translocation of building plans to different sites.

Adebayo, (2000), opined that efficiency in skill and experience is important in creating valuable workmanship in building construction. Ayinuola et al, (2004), pointed accusing finger to all parties in the building industry, clients, architects, engineers, town planners in the local authorities and contractors stating that they

have contributed to building failures in various dimensions.

Tyagler et al, (2007) traced the causes of building failures to defects or deficiencies at design and construction stages.

Ukpata, (2006), opined that the spate of building collapse in the country can always be traced to unsafe actions of parties involved in building process starting from clients to building consultants, contractors and users.

Adebayo, (2006), opined that building collapse incidences can be controlled or minimized if the client is ready to pay for high quality materials and for expert professional services. A basic building consists of four components:

i. Structural Component - Which are the load bearing elements of the building and they are slabs, columns, staircase, foundation walls and can be made of steel or concrete.

ii. Semi- Structural Component - Are walls and roofs, then also take some loads.

iii. Non - Structural Components Doors and windows.

iv. Services - Are pipe for waste and fresh water into and out of the building and 
also for electric cables used for electricity supply etc.

v. Afolabi (2000) described that failure could also be expressed as when a building cannot be useful anymore for its special

\section{Patterns of Failure and Causes}

During concrete making, if the production and placement satisfies the provided relevant codes of practice, it will gain greater strength overtime. Otherwise problems like cracks and collapse may occur which can be due to shrinkage, thermal expansion or contraction. In a situation where chemicals particularly sulphate is being absorbed, it may cause corrosion of reinforcement, which may lead to structural failure. Bricks are affected by moisture and where salts abound, efflorescence occurs outside or inside.

Defects in timer is mainly due to moisture in-balance and attacked by biological life e.g. ivy, moss, lachrymose etc.

Metals corrode in the presence of moisture and oxygen and may be subjected to loads beyond its stress limit due to poor design.

Okpo (1990) in his book identified that the nature and level to which environmental agencies will affect a building depends on the location of the building. In addition, there is inequality or difference between the survival limits of public estate and private one.

An analysis within the defect reporting system of the Property Services Agency showed that $51 \%$ of the causes of defect were due to short comings in design, $28 \%$ to inadequate workmanship, and the remaining were due to other purpose. If total failure occurs in a building adjustments can no longer be rendered to it but if a partial failure occurs then adjustment can be made on it to restore it back to initial state by a skilled and experienced engineer. causes including the failure of materials. A recent Building Research Establishment study into faults in conventional two-storey building in England showed that $50 \%$ were attributed to design $41 \%$ to site and only $8 \%$ other causes including materials.

\section{Failures in foundation}

\section{Soil Movement}

Ransom (1987) cites that soil contains water which is forced out of the soil and soil particles moves close together when the soil is loaded by the heaviness of weight of the foundations and imposed super-structure.

As these processes occur, the ground is compressed and the foundation eventually settles until equilibrium is reached between the imposed load on the soil and forces between its particles.

Settlement is faster with sand compared to clay soil and particularly ends by the time the building is finished. The more clay that is contained in the soil the longer it takes to attain equilibrium. After the foundation settlement has subsided, it can lead to crack formations on the wall or part of the building due to unevenness in the settlement.

According to Obieghu (1998), foundation failures may be due to several causes, which could be: 
a. Unstable conditions caused by inadequate foundation

Width of the foundations spread not wide enough to support the building load.

\section{i. Overloading -}

Due either to additional loads being applied to the foundation because extension work has been constructed upon the original building or because the use of the building has been changed and the imposed loads upon the floors increased. In each case the loads imposed upon the ground are greater.

\section{b. Changes in ground condition}

Conditions may occur below ground level, which may directly affect the bearing capacity of the soils, either improving it with no detrimental effects or lowering it. These changes may occur because

\section{i. Changes in water content of the soil -}

The lower the moisture content the greater the bearing capacity, and consequently any increase in moisture content will cause lowering of bearing capacity. Dry hard have a high strength but, with an increase in moisture content they become plastic and compressible. Therefore the infiltration of water will ultimately affect the support of building and allow settlement movement of the structure

\section{ii. Surface Water}

This is caused by natural rainfall upon the ground draining into the ground. Continuous and concentrate amounts in areas of poor directional drainage can cause saturated conditions, which will affect the bearing capacity of the soil. Flooding occurs for a short time and the water recedes. However, while the situation exist the ground soils and the structures above and below ground level are affected. The effects are not always immediately apparent at the time of flooding, but may appear at a later time.

\section{c. Ground Movement}

Any movement of the ground will affect the support of any building and the actual structure above. The movement may be causes in several ways, such as biological faults, mining, subsidence, vibrations and unequal settlement.

\section{d. Building on Slope}

Building erected on sloping ground are normally stable after a suitable period, although changes in ground water could affect and gravels, whereby the building might settle and also slip down the slope. Retaining walls may fail if subjected to excessive pressure.

\section{e. Chemical Attack}

Attach by sulphate or acid substances in natural ground is rarely sufficient destructive to cause significant damage to shallow foundations of low rise buildings. Aggressive chemical compounds in fill material can, however cause disintegration and expansion of ground bearing slabs and foundation block walls.

\section{f. Consolidation of poor or made ground}

In these circumstances progressive damage is likely to occur within the first ten years of life of the building. It Is advisable to obtain all available information about the history of the site from local residents, geological maps etc.

\section{g. Existing trees}

Existing trees near the building may cause foundation movement. Where trees have reached or area close to maturity, seasonal shrinkage and swelling movement can be expected, but larger movements will 
probably occur only in long periods of dry method of reducing the harmful effects of the trees.

\section{Failure In Hardcore and Floors}

Hardcore are small pieces of stones, used as a base for building which are also free from damaging matter and water stable that might cause damage to the concrete. Soluble sulphate in hardcore can caue harm to concrete floor. Solutions of sulphate can also attack the set cement in concrete. Major arching and lifting can occur as attacks continue, the concrete surface tends to crack and movement of the external walls may occur too. Hardcore consolidation after the building has been completed if it is not properly compacted which may cause a solid ground floor to be weak over its whole area.

This likely happens when the depth of the hardcore used is excessive or where deep trench fill has been used for foundation, thus the solid slab is likely to sink and crack particularly towards the edges under which the depth of hardcore is greatest; the first sign of the trouble is usually the appearance of gaps between the floor and the skirting and cracks may appear in partitions.

Ransom (1987), stated that failure associated with floor screed may be as result of poor bond, shrinkage stress and lead to crack with tendency to curl at the edges of the crack.

If the screed is tapped the floor sounds hollow. Finishes applied over it such as tiles and sheet covering are also likely to crack and split and ultimately loose their adhesion to be screed. Failures in terrazzo include cracking and grazing and lack of good bond to the screed.
Failures in timber flooring are mainly caused by moisture for this can cause decay and movement; timber subjected to changes in moisture can deform by bowing and twisting, and may crack if movements are frequent.

\section{Failures in Walls}

These are two types of failures associated with walls and they are failure to provide adequate protection against moisture penetration and cracking of the walling materials, which was described by Ransom (1987).

Rising dampness in the walls is likely to cause damage to the plaster and decoration, particularly when hygroscopic ground salts are brought up in solution.

Dampness due to complete absence of damp proof course is continuous and can extend to several feet in bad cases.

However, inadequate laps in flexible DPC's can also lead to moisture penetration. Laps should be least of $100 \mathrm{~mm}$ and damp proof course laid on a fill mortar bed and also fully covered with mortar above to prevent damage. Walls have been protected traditionally from rain and its effect through eaves, canopies, cornice, strong courses and other forms, the ability of wall to exclude rain thus depends partly upon such design features, but principally upon its topographical and geographical and construction method involved. Rains is likely to penetration solid brick or block work, which is not rendered directly through cracks in the mortal, and between mortar and brick or block. The risk of which is increased if the mortal is of poor quality and if the vertical joints of mansory are filled in adequately. 


\section{Cracks and Spallin In Walls}

Cracks in walls may occur due to roof movement, it occurs mainly through weakening of the structural members of a roof with time. As the root spreads, it moves the top few courses of the wall mensory outwards slightly; horizontal cracks appear in the plaster on the internal wall, close to eaves level and cracking may also be seen externally.

The movement of concrete roofs could cause common defects in walls. These can be caused by directional changes in temperature especially If the surface finish is dark in colour. The roof then tends to move outward at the top of the walls, and may push the top courses of mansory out slightly, this cracking occur within the internal plaster finish. These could be noticed near the corners of the building, close to junction of the roof with the wall. Low quality blocks can as well involve cracks on walls.

Obiegbu 1992, reported that the compressive strength of the locally produced blocks from 14 blocks industries in Enugu were found to yield in average compressive strength of 6 blocks (1:6) of $0.86 \mathrm{~N} / \mathrm{mm}^{2}$ to $1.3 \mathrm{~N} / \mathrm{nn}^{2}$ at 7 and 28 days respectively. Whereas the industry standard as recorded in Federal Ministry of Works and Housing Laboratory at of 1962 is $1.10 \mathrm{~N} / \mathrm{mm}^{2}$ to $2.07 \mathrm{~N} / \mathrm{mm}^{2}$ at 7 and 28 days respectively.

\section{i. Dampness in walls}

The absorbed moisture may cause expansion and contraction and can produce shrinkage, cracks which can be pronounced in certain instances. There is possibility for moisture present to cause deterioration of materials, surface finish and decoration.

Sources of dampness include

i. Direct penetration through the surface due to porous block work.

ii. Rising dampness in solid floor due to ineffectiveness damp proof around door and window opening.

Rendering may crack and become detached from their background, however in the absence of sulphate attack, through, differential movements between the background and rendering.

The effect of shrinkage of rendering on rigid background is to set up stresses, which may be relieved by cracking or by loss adhesion. Rensom (1987) cited I his book that cracking from shrinkage in the absence of sulphur attack is likely to be random and if tapped the rendering may sound hollow.

\section{Failure in Roofs}

Ransom (1987) stated that, in general, it can be said that pitched proofs have given few problems and flat roofs have given many problems. Flat roofs fail because they let rain through, water is trapped which afterwards drips out, or moisture generated within the building condenses and drips back. Moisture from the last two causes can also assist in the breakdown of the water proof covering which may lead to rain penetration. With some roof deck, the confined pressure of moisture has been a contributing cause of structural failure and however, insufficient slope to the roof cause a major leakage. 
Rain leakage through roofs following splitting and deterioration of the water proof covering has been due, impart to failure, to recognize or to allow for sufficient moisture and thermal movement to which flat roof systems are prone, to the adverse effect of standing water and solar radiation, to blistering caused by pressure of entrapped moisture or air, to inadequate detailing at parapets and projects; to decay and collapse of some materials used decking or for insulation and to mechanical damage.

It was also stated by Ransom (1987) in his book that few problems arise with pitched roofs, but in recent years some troubles have been experienced with overall instability of trusses rafter roofs. There have been cases where trusses have collapse or moved laterally whilst remaining parallel to another. This has been caused by omission of diagonal brassing and the faults, is manifested initially by displacement of roofing tiles. It not corrected, the failure can lead to rain penetration, breaking rafters and cracking of gable walls. In some cases failure of the whole structure has occurred through inadequate of roof design.

Corrosion of galvanized steel fasteners has also been the contributing factor to major failure.

In order to ascertain and identify the various cause of building failures in the area under study, surveying of the various site in the area under study was carried out and data was extracted from textbooks, magazines and journals.

Plate 4.1: Failure in concrete floor due to penetration of tree roots.

The root damage results most obviously from the penetration of tree roots into mansory and beneath foundations and rupturing due to
The following are the defect likely to occur in roof structure as reported by Obiegbu, (1998).

i. Sagging and deformation of roof; roof may sag due to overload; inadequate sizes and strength of structural members, decay due to attack of roof structural members by rot and extensive wind pressure.

ii. Leakage water may leak or overflow points along the drain pipe or the gutter. This may be due to blockage, loose joint, overflow of the concrete deck leakage. The leakage cause dampness to external and internal walls and noticed underneath the concrete gutter soffit.

iii. Cracking of asbestos sheet, rusting of galvanized sheet, roofs structure are liable to move as a result of thermal changes and wind loading. The induced stress on this do also ago will set in and deteriorate asbestos sheets, which have about 15 year life span. For galvanized sheets, corrosion is itself liable to corrosion.

progressive root growth. Such damage can usually readily be identified by excavation and does not justify special comment, except in relation to safe separation between trees and buildings.

4.2: Failure in concrete floor slab due to excessive shrinkage of the screed.

Concrete floor slabs are not usually cast with a finished surface but are usually topped with a separate screed finish. The mix is either basically a fine aggregate concrete or a mortar. 
One of the most common problems in screeds in random fracturing or crazing which is due to excessive shrinkage of the scree, if the bond to the concrete is also poor, curling or lipping at bay edges will also develop. Screed must be kept slightly damp or at least protected from evaporation, for about 28 days to ensure proper hydration of the cement and the development of full strength.

Plate 4.3: Failure in concrete floor slab due to inadequate compaction with a weak base.

Many floor layer have encountered crazing and curling problems; in fact, such inadequate mixtures of cement results inadequate distribution of the cement, particularly if normal drum mixers are used and such mixers are also difficult to compact, resulting in screed with a rich surface where it has been worked but with a weak base so that the screed can easily be damaged by high loads.

Plate 4.4: Failure in ceiling boards due to leakage in roof covering. Failure in ceiling board due to leakage in roof covering, this leakage water may occur due to loose joints or through holes which drops on the ceiling boards.

Plate 4.5: Diagonal crack in wall failure as a result of differential settlement. In extreme cases diagonal fractures may be identified as resulting from the settlement of a distinct part of the structure, but in other cases fractures, general through openings which represent the weakest pasts of walls will be wider at the tops of the walls than at the bottom, indicating that local settlement has occurred to one side of the fracture. Such damage is common on inadequately compacted fill, on land with patches of fill, or on sloping sites where walls are on excavated ground at one end but on fill on inadequately compacted ground at the other.

Plot 4.6: Failure due to plumbing problems and differential settlement.
Water and sediment in foul- water drains rapidly becomes anaerobic through the high organic content of the sewage, encouraging the development of anaerobic bacteria such as sulphate-reducing bacterial. These bacterial encourage rapid metal erosion of iron and steel pipes. Sulphate-reducing bacteria liberate hydrogen sulphide gas into the air space before the sewage and thus are absorbed by condensation where it is rapidly converted to sulphate by the action of oxidizing bacteria, causing severe sulphate attack damage to mortar joints, rendered surfaces and concrete.

Plate 4.7: Failure of reinforced concrete slab due to inadequate concrete over (spalling)

If cover over reinforcement is inadequate corrosion becomes apparent as unslightly patches of brown straining and brown water runs. However, progressive corrosion of reinforcing bars results in expansion and spalling of the concrete surface which is unslightly, as well as being destructive and dangerous. Various methods have been proposed for repairing this damage, usually by cutting out the spalling concrete fully to expose the corroded reinforcement, removing the corrosion and treating the reinforcement with tar, bitumen or resin coatings In an attempt to inhibit further corrosion as far as possible. A creamy cement slurry is then applied to the reinforcement and spalled surfaces, and the spall is filled with a matching concrete mix.

Plate 4.8: Failure of roof caused by fungal decay and rusting of roofing sheet.

If wood remains very wet continuously, soft rot fungi are likely to develop causing softening of the surface of the wood to a progressively increasing depth. However, if intermediate dampness exists in which the wood has an adequate moisture content without being waterlogged so that they is free 
access to oxygen in the air, wood destroying fungi can develop. The use of overhanging eaves and efficient rain water disposal systems are examples of structural precautions which are significant I decay prevention. It is often claimed that painting wood, protects if from rainfall and thus preserves it against decay.

Plate 4.9: Failure caused by environmental factor, water erosion and wind. Environmental factors such as heavy rainfall, water erosion and wind action are also factors that can lead to building failures in the study area.

Plate 4.9.1: Failure in painted wall due to water penetration (Blistering)

The main causes of failure in paint work are

i. Adhesion Failure: Application to damp, dirty, powdery, friable, dense or unpaired substrates;

ii. Cracking: Undercoat has not hardened sufficiently before finishing coat applied, and/or stresses

iii. Chalking: Often results from slow erosion on lengthy exposure;

iv. Blistering: Usually results from liquid or vapor beneath the coating.

v. Discolouration: May result from use of paint in unsuitable conditions; chemical attack or possibly lengthy exposure to bright sunlight;

vi. Loss of Gloss: After length exposure

This particular failure may arise through dampness, drying out of new construction often takes an unacceptably long time and there is often a reluctance to accept temporary decoration. Surfaces to be painted must be sound and certainly not powdery of crumbly. Special paints are available for specific purposes, such as anti-condensation paints with insulating or absorptive properties. To prevent the decay of building components, it is essential that repainting takes places before the existing paint film begins to breakdown. Saving on painting and decoration is frequently false economy as it is merely storing up much greater and more costly problems for the failure.

Plot 4.9.2: Vertical crack in wall due to straight jointing and differential settlement.

Failure as a result of differential settlement could be an indication of inadequate design in relation to ground conditions or failure to follow the design during construction. Certainly, the worst settlement problems are associated with sites in which the load bearing capacity of the ground varies so that part of the foundation settle, sometimes causing massive structural fractures to joints. 


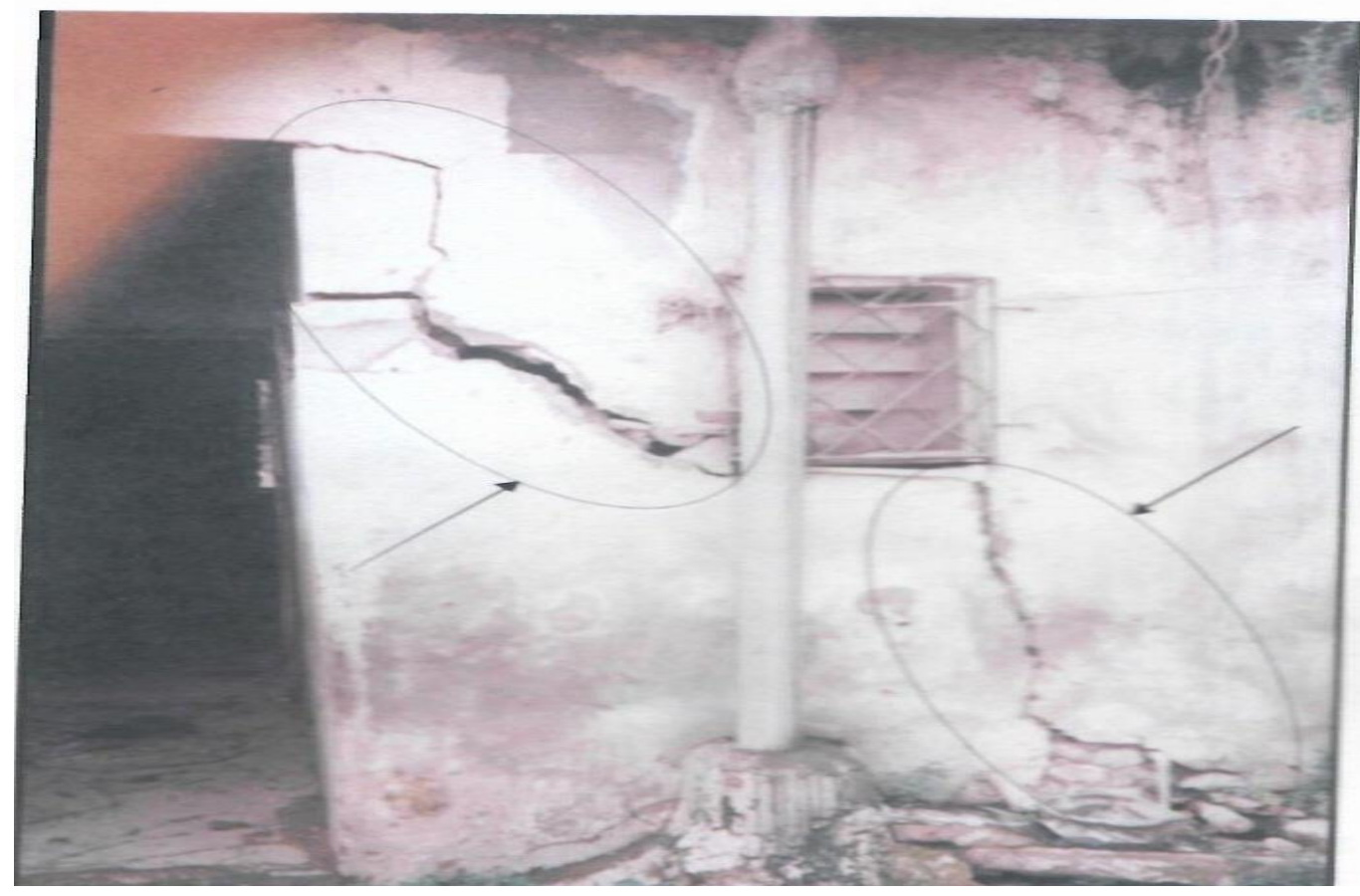

Plate 4.5: Diagonal crack in wall. Failure as a result of differential settlement and drainage system poor

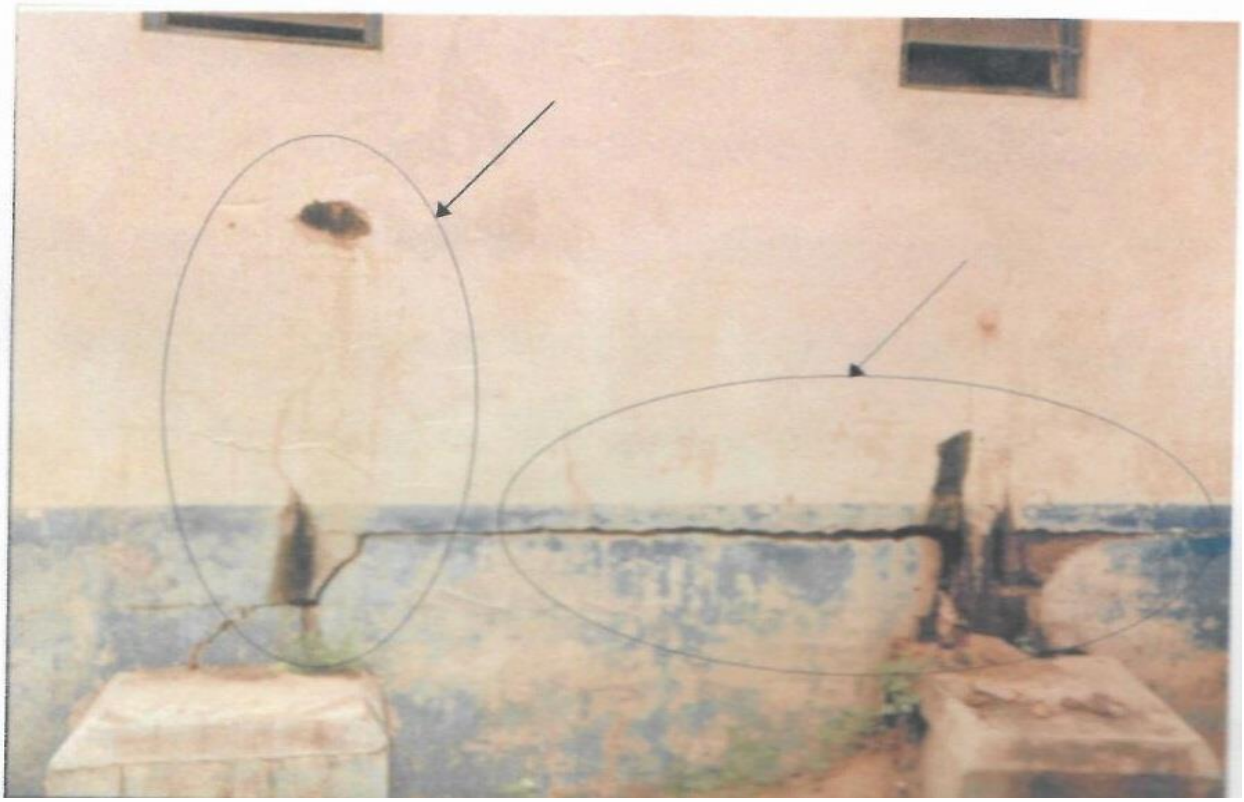

Plot 4.6: Failure due to plumbing problems and differential settlement. 


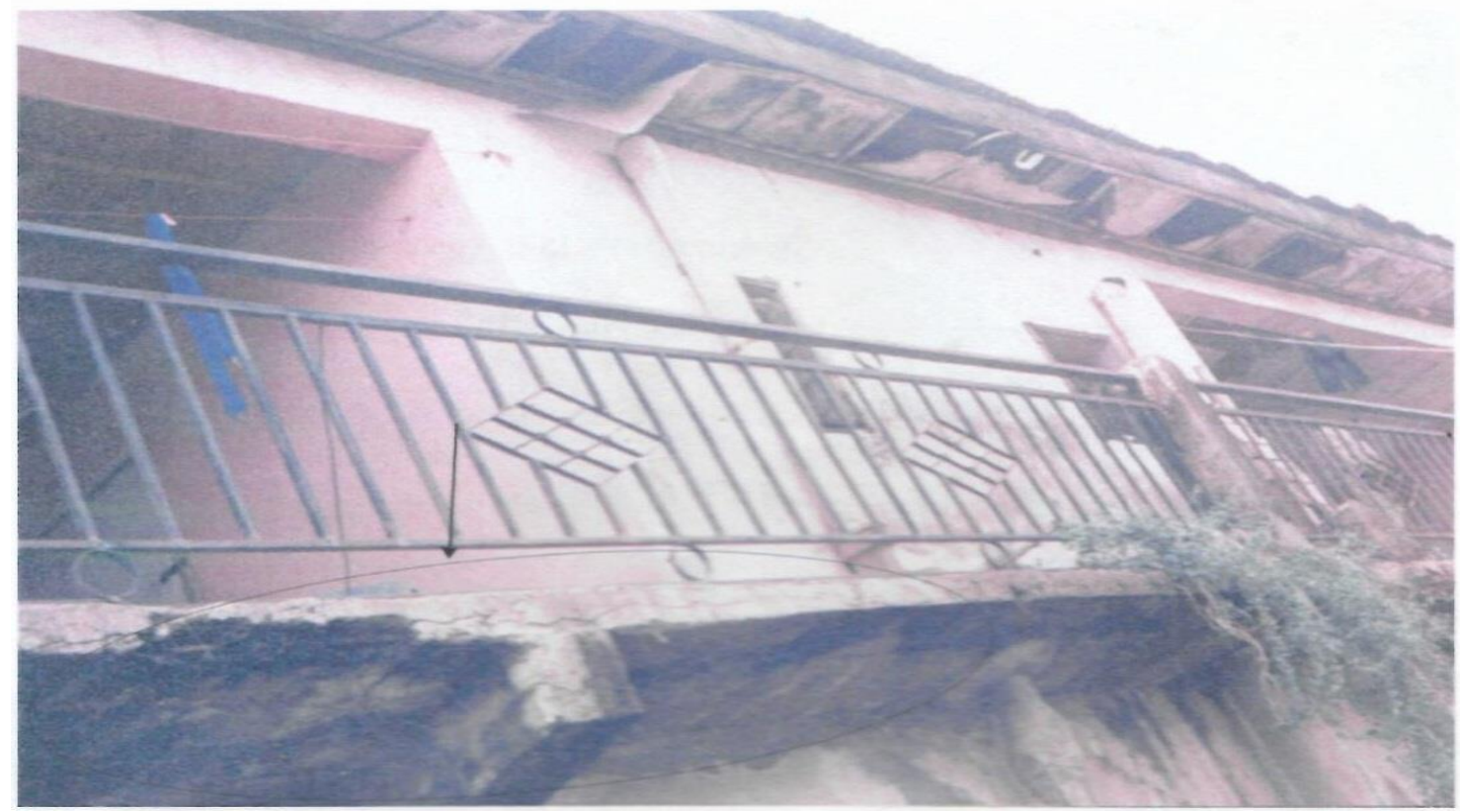

Plate 4.7 Failure in reinforced concrete slab due to inadequate concrete Cover (spalling).

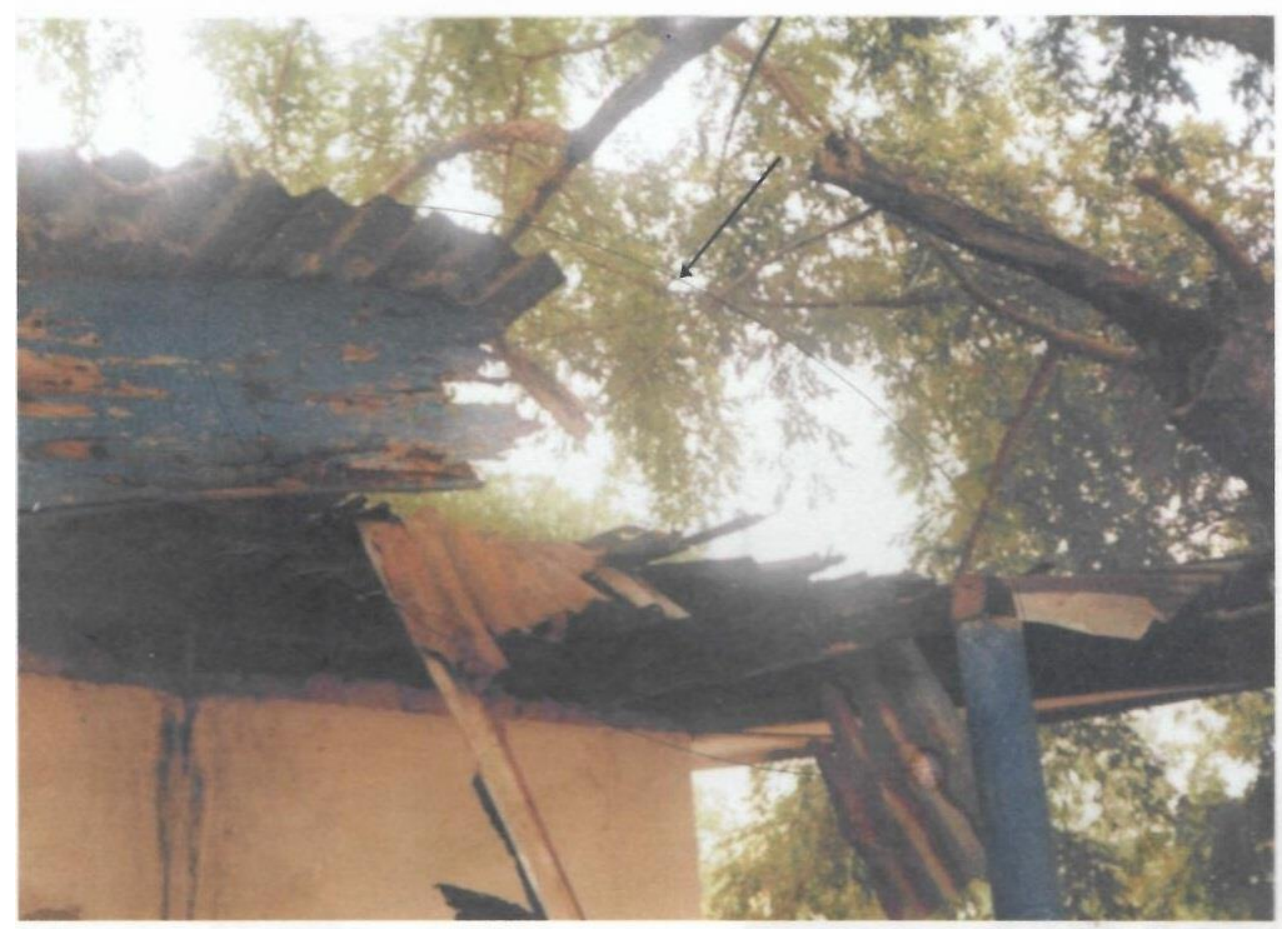

Plate 4.8: Failure of roof caused by fungal decay and rusting of roofing sheet. 


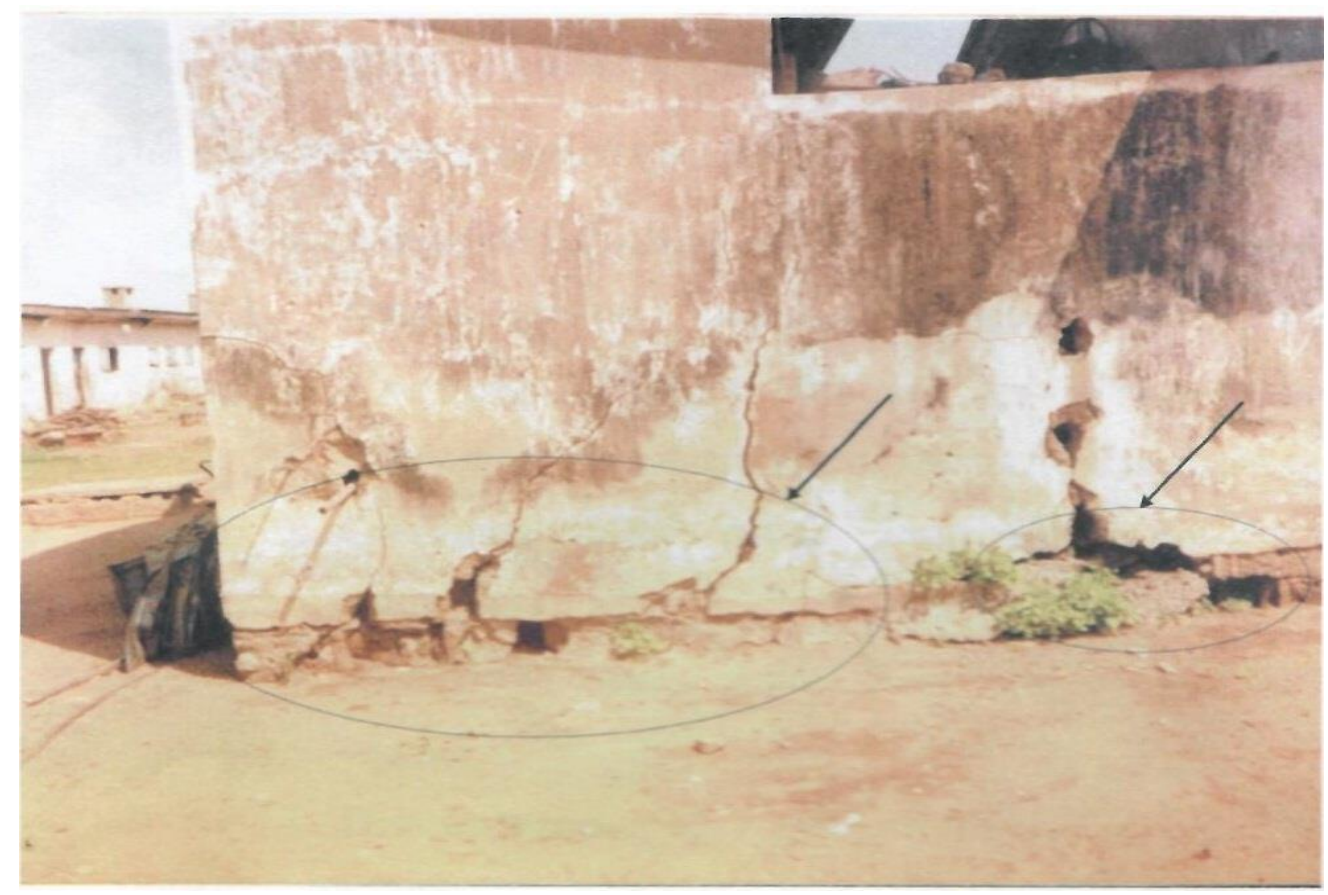

Plate 4.9: Failure caused by environmental factor, water erosion and wind.

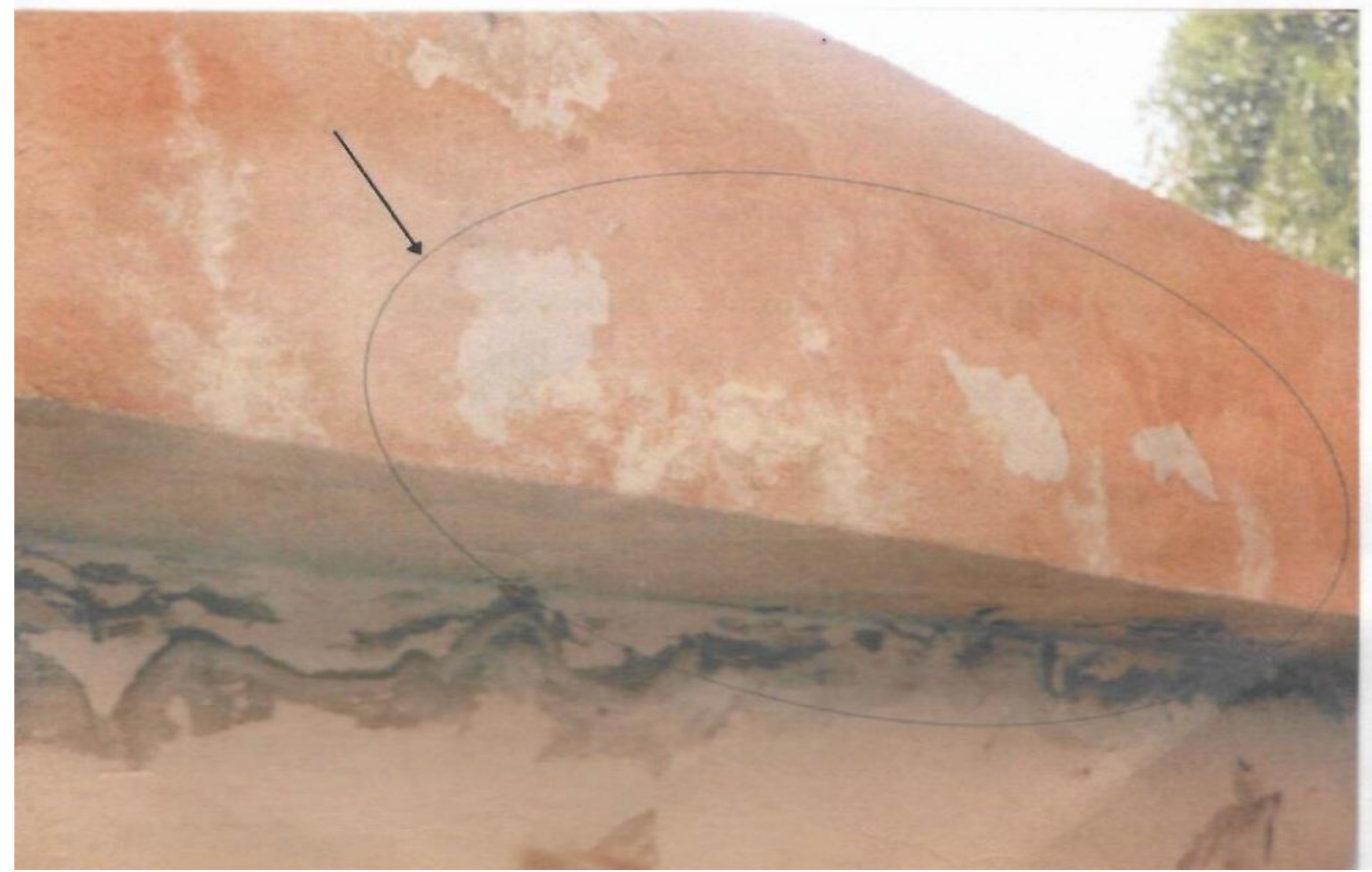

Plate 4.9.1: Failure in painted wall due to water penetration (Blistering) 


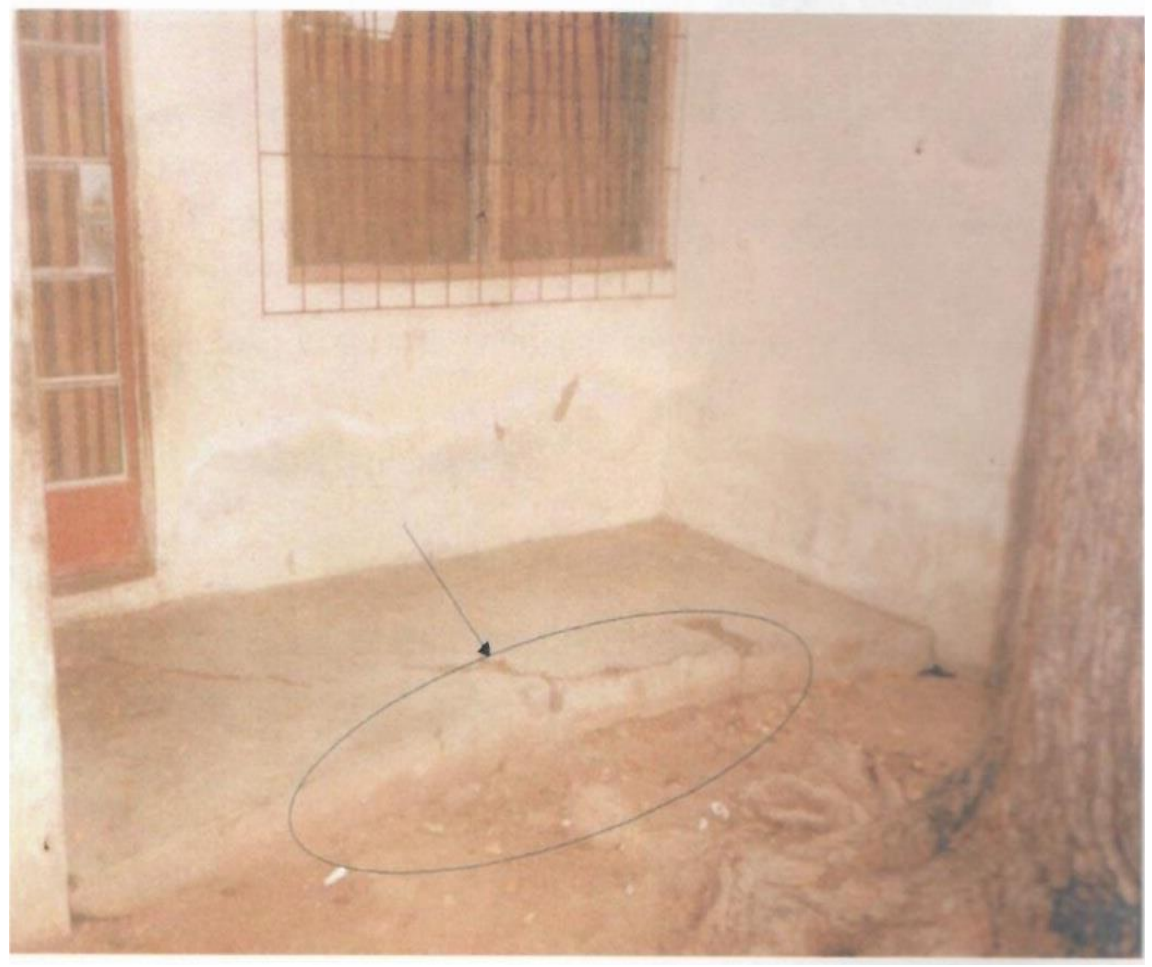

Plate. 4.1 Failure in concrete floor due to penetration of tree roots

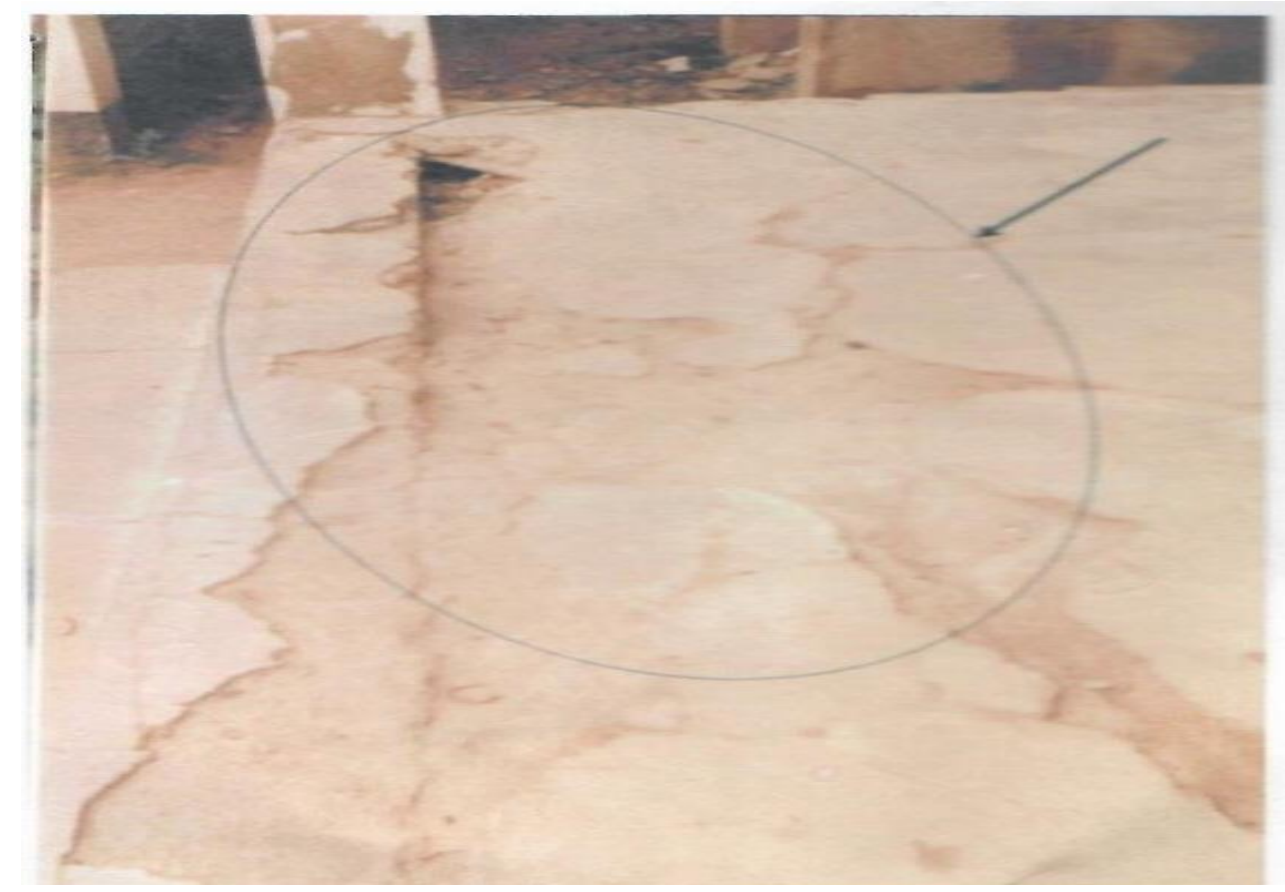

Plate 4.2: Failure in concrete floor slab due to excessive shrinkage of the screed 


\section{Planning Stage}

A building consist of two parts namely the sub-structure and the superstructure. The sub-structure is the part below the ground level where the foundation is found and caries all the super-structure with the load. The superstructure is the part above ground level. The sub-structure transmits the load imposed by the super-structure to the earth effectively.

Since the earth is the support of all loads and soil vary with depth from place to place, there is necessary need for adequate knowledge of the particular soil on site before any design is made. The important parameter that are vey necessary here are density, moisture, content, void ratio, soil texture, angle of friction, adhesion and they can give an approximation of the soil bearing capacity which is important In foundation design. An error in the soil bearing capacity would lead to foundation failure. For instance, if the soil bearing capacity should be $30 \mathrm{~N} / \mathrm{m}^{2}$ and one uses $40 \mathrm{~N} / \mathrm{m}^{2}$, this giving the soil more load that It can bear. The type of foundation includes strip, pad, raft and pile.

\section{Design Stage}

This stage determines the existence of a building and comes after the planning stage. The structural design provides the skeleton of the potential building in agreement with regulation for practice. The structural design provides an appropriate section for the elements and the necessary reinforcement (for RC Structures) to support the potential load.
Structural designs are scaled to conveniences especially for a typical storey building and detailed as follows;

a. Outline of the floor is drawn to scale and divided into supportable sizes called panels.

b. The beams are made to be supported by columns.

c. The columns are provided with good footing in the ground.

Building faults could occur in this design stage due to:

i. Errors in calculating number of reinforcement and improper design procedures.

ii. Errors in translating calculations into drawing

iii. Mistake in the determination of the maximum bending moment and maximum shear forces necessary to choose the members.

iv. Unsuitable loading estimate, this include both dead load and imposed load.

\section{Construction Stage}

This is the stage of transforming the engineered ideas into reality and done at the site described by Afolabi (2000). The construction stage also involves the use of materials and labour. The approaches here are as follows:

a. A layout of the proposed building is done on the ground

b. Excavation for foundation base

c. Making of foundation

d. Column making

e. Beam making

f. Making of slabs 
The structural drawing provided above serves as guides in this process. Adequate monitoring needs to be made for good quality work in the making of reinforced concrete. Adequate monitoring is also needed during the making of form work so as take the concrete during the concrete production monitored from batching to placement and making sure reinforcements are as specified and placed properly.

\section{Usage and Maintenance}

The building is put into use after construction of which a normal building Is supposed to remain standing for a reasonable period of time before depreciation.

The kind of faults that can occur in building from the manufacturing stage to the usage and maintenance stage include the following:

i. Crushing of column.

ii. Sagging of slabs panels, staircases and beams

iii. Cracks on structural elements, slabs, beams and columns

iv. Even-settlement and differential settlement.

v. Collapse of part of the building.

vi. Total collapse of the building.

\section{i. Crushing of Column}

Crushing is a compression member, hence a vertical member in a frame structure that supports beams. A mistake in the design and construction of a column can cause damage to it during use. ii. Sagging

This is a droop or curved deflection. There is deflection in all structural members due to their response to load imposed on them, because of this there is a provision for maximum deflection allowable for any element with respect to their end conditions and span design in all structural design codes.

For safety during design it must be certain that the permissive deflection is not exceeded to avoid the results such as deflection.

\section{iii. Cracks on Structural Elements}

Cracks are opening due to strain on structural members which might expand with time. This may be unsafe because it stops the structural member from acting as one; which disproves the assumption in the analysis of a flexural member that allows continuity to the supports. Some of the reasons for cracks in building are

a. Existence of more than the design load on the elements.

b. Inadequate availability of shearreinforcement

c. Reinforcement are needed to take care of tensile stresses in beams and slabs and when not adequately provided concrete will be weak in tension.

\section{iv. Settlement}

This occur due to inadequacy in the approximate bearing 
capacity value used for the soil in design. Settlement is the vertical downward movement of a building in the ground.

This is uniform settlement when the whole building in plan moves downward at the same rate; this is manageable if the rate is very slow. It is even if there is relative movement of the building in plan downward into the earth. If there is a noticeable uneven settlement it is alarming and could cause destruction and damage to life and properties, it is better to leave the building.

According to design and specification, the maximum differential settlement must not exceed $40 \mathrm{~mm}$ in clayey soil and $25 \mathrm{~mm}$ in sandy soils, the angular distortion of the frame of a building must not exceed Summary of Result

From the findings and result obtained in this research, it is discovered that the majority of building failures in the area under study is caused by environmental factors, such as water erosion,, rainfall and wind action. Factors like
1:10000

(vertical

to

horizontal).

v. Collapse of part of a building

Part of a building may suddenly give way without warning as a result of a mistake in the stages in making a building.

\section{vi. Total Collapse of Building:}

A whole building may collapse during and after construction or during use without any warming due to any error or mistake in th course of a making a building.

inadequate supervision, poor execution method as well as poor maintenance can be mentioned among the existing building, poor design at the initial stage, human negligence, making use of inferior materials also contribute to the failtures in building. 


\section{Conclusion}

It can be concluded from the findings that the most common factors responsible for the causes of building failures in the area under study are ranging from environmental factors, inadequate supervision, poor execution method, poor maintenance, poor design at the initial stage, human negligence and

i. Proper and adequate supervision and control of work on site should be adopted in order to enhance a proper execution of the work according to specification and available codes.

ii. Provision should be made for a good drainage system, as well as proper waste disposal in order to avoid the risk of overflooding.

iii. The roof designer while designing should take into consideration the effects of wind forces on the roof.

iv. Government should convert her estate to be owner-occupier so that the proper management could be undertaken by the owners.

v. Government should enforce the use of maintenance policy and employ some professionals to be engaged in ensuring this policy is used by people properly. making use of inferior material. The solutions varies from adequate supervision, if effective execution method, adequate maintenance, effective design at the initial stage and making use of original materials and proper use of specifications and available codes.

Based on the above findings, the following recommendations are adopted.

vi. inally, to overcome problems like that of foundation, the nature as well as the bearing capacity of soil available in the area under study should be investigated, before the foundation type can be selected. proper planning, supervision and monitoring of construction activities should be

Institutionalized by policy makers to ensure that all buildings are constructed According to design, specifications and planning regulations.

Professionals in the building industry should maintain their integrity and professional ethics and work in accordance to standard practice procedures laid down by the standard form of building contracts especially when they play in the hands of ignorant clients Urban or Town development agencies at various levels of government (commission, Board, Authority) should enforce control of building works in their localities as laid down in urban and regional planning decree 88, of 1992 and as in section 13 of National Building Code 2006. 
There is need to organize periodic public awareness campaign through electronic and print media to sensitize the public on advantages of using professionals as the way of realizing safe buildings.

Standard organization of Nigeria should be vigilant to ensure that building materials imported into the country conforms to standard requirements. All building professionals play key roles to actualize their respective obligations during building production, using the wrong professionals at any stage of the building process put the building in danger. It is the duty of the architect as the prime consultant to direct the client to use the right professionals. This he achieves by ensuring that the structural and services drawings brought to his office are stamped and signed by professionals registered by their respective professional bodies before proceeding to planning authority for "building permit". Soil investigation, material tests and environmental impact assessment (E.I.A) should be made compulsory for all institutional, industrial and commercial buildings. 


\section{References}

1. Adebayo, S.O (2000): Improving Building Techniques "Proceedings of Workshops on

Building Collapse: Causes, Prevention and Remedies. The Nigerian Institute of Builders, Lagos State.

2. Arayela, O and Adam J.J (2001): Building Disasters and Failures in Nigeria. Causes and

Remedies. Journal of the Association of Architectural Educators in Nigeria (ARCHES).

Vol. 1 No. 6 Sept. 2001.

3. Ayedun, C.A, Durodola, O.D and Akinjare, O.A (2012): An Empirical Ascertainment of the Causes of Building Failure and Collapse in Nigeria. Mediterranean Journal of SocialSciences. Vol. 3 (1). January, 2012.

4. Ayininuola, A. J., \& Olalusi, O. O. (2004). Assessment of Building failures in Nigeria: Lagos and Ibadan case study. African Journal of Science and Technology, 5, 73-78.

5. Babalola, H. I. (2015). Building Collapse:

Causes and Policy Direction in Nigeria. International Journal of Scientific Research and Innovative Technology, 2(8), 1-8.

6. Ede, A. N (2010a) Structural Stability in Nigeria and Worsening Environmental Disorder:

The way forward. The West African Built Environment Conference Research Conference, Accra, Ghana, July, 76-78, PP. 489-498.

7. Folagbade, S. O. (2002). Case Study of Building collapse in Nigeria. In
Proceedings on building collapse: Causes, Prevention and Remedies, Ondo State, Nigeria: The Nigerian Institute of Building (pp. 110-121).

8. Ikpo, I.Y (1998): Application of Weibull Distribution Technique in the Prediction (MTBF) of Building Component. Nigerian Journal of Constructions Technology and Management. Vol 1 No 1.P 79-87

9. Madu, L.C (2005): Journal of Nigeria Institute of Architects (N.I.A) Architecture: research \& Practice Vol. 1. No. 3 November 2005. ISSN 1597-2947. PP.

10. Mohammed, L.Y (2011): An Overview into Procedures of Disputes Resolution in Construction Industry. Journal of Environmental Research and Policies Vol. 6. No.3 2011.

11. Odeyemi, S. O. (2012). Effect of Types of Sandcrete Blocks on the Internal Microclimate of a Building. Journal of Research Information in Civil Engineering (RICE), Department of Civil Engineering, University of Ilorin, llorin, Nigeria, 9(1), 96-107.

12. Omenihu, F. C., Onundi, L. O., \& Alkali, M. A. (2016). an Analysis of Building Collapse in Nigeria (19712016): Challenges for Stakeholder. Annals of Borno, XXVI, 113-136.

13. Oseghale, G. E., Ikpo, I. J., \& Ajayi, O. D. (2015). Causes and Effects of Building Collapse in Lagos State, Nigeria. Civil and Environmental Research, 7(4), 34-43. 